\title{
AMERICAN WASPS OF THE GENUS SCELIPHRON KLUG
}

\author{
By Bennet A. Porter \\ of the Bureau of Entomology, United States Department of Agriculture
}

\section{INTRODUCTION}

The conspicuous black-and-yellow thread-waisted wasps of the genus Sceliphron are familiar to all who have taken the least notice of insect life. Equally familiar are the mud nests which these wasps construct on the timbers of buildings and elsewhere, inclosing within them spiders for the sustenance of their progeny.

The paper here presented, dealing with the genus Sceliphron, is a portion of a study made by the writer in 1916 while a graduate student at the Massachusetts Agricultural College, in partial fiulfillment of thesis requirements for the degree of doctor of philosophy. Since entering the service of the Bureau of Entomology the writer has had opportunity to study all of the material of this genus in the collection of the United States National Museum, which has aided in clarifying certain points which were in doubt.

In $1918 \mathrm{Kohl}^{1}$ published a revision of the wasps of the subfamily Sceliphroninae of the world. In this paper all the species of the subfamily are placed in the genus Sceliphron. To this and certain other points of interpretation the writer can not agree; they will be discussed in detail below.

The present paper is in a sense supplementary to Dr. H. T. Fernald's studies of the Sphecinae and Chlorinae, other subfamilies in the family Sphecidae. Hearty thanks are hereby expressed to Doctor Fernald for the active interest which he has taken in this study and for assuming the responsibility for material loaned by a number of institutions and individuals. Thanks are also due to Guy C. Crampton for helpful suggestions regarding the anatomy of the group of insects under consideration, and to S. A. Rohwer for facilitating in every way possible the work of the writer at the National Museum.

1918, Kohl, Franz Friedrich. Die Hautflugler gruppe “Sphecinae," IV Teil, Die naturliche Gattung Sceliphron Klug (Pelopolus) Latrielle. In der Annalen des Naturhistørichen Hofmuseums Wien, vol. 32.

No. 265.-Proceedings U. S. National Museum, Vol. 70, Art. I $3017-26-1$ 


\section{TERMINOLOGY}

Except for the terms used in connection with the male genital structures, which have not been used by other authors very extensively in the interpretation of relationships in this group, the terminology employed does not depart from that in general use among the students of the aculeate Hymenoptera, and need not be defined in detail here. The explanation of the plates which accompany this paper will doubtless give sufficient information.

\section{MALE GENITALIA}

The terminology used to designate the various genital structures seems to be in a state of confusion, and very little has been done to establish a uniform system of nomenclature throughout the different groups. The terms used in this paper are only tentative, and further study may show the desirability of changes. The parts of the genital structures in the genus Sceliphron have provisionally been designated as follows: (1) Basal ring (cardo), (2) claspers, (3) uncus, and (4) combined volsellae and sagittae.

The basal ring is narrow throughout, and especially so on the dorsal side. It surrounds the basal part of the genitalia.

The claspers are long and stout, and almost entirely enclose the other parts above. Dorsally and ventrally at the base, arms project inward; the dorsal arms seem to just about meet, and the ventral ones overlap. Near the tips of the claspers are a few scattered hairs.

Articulating with the dorsal basal arms of the claspers is a structure which I have tentatively termed the uncus, consisting of two structures loosely connected by a membrane three-fourths of their length. The distal portions, which are not connected by this membrane, are more heavily chitinized and are more or less curved or hook-shaped. Structures similar to this uncus in some Hymenoptera are termed by Radoskowski the "crotchets."

Ventral to the uncus, and arising near the ventral basal arms of the claspers is a structure, presumably consisting of the volsellae and sagittae, which have become more or less fused. Taken together, they are similar to a structure which Radoskowski calls the "bouclier". It consists of a large basal portion divided except at the very base, possibly representing the volsellae which have become partially united, and of two smaller structures fused to the inner distal edges of the volsellae and possibly representing the sagittae.

The genital structures except the claspers are concealed ventrally by the subtriangular venter of the eighth abdominal segment, which is partly telescoped under the venter of the seventh segment.

The genitalia have proved useful in determining specific relationships. Thus genitalia of the different forms here placed under 
caementarium present no essential differences, supporting the belief that the whole series constitutes but a single species. Those of fistulare and fasciatum are plainly distinct. Those of lucae are somewhat similar to those of caementarium, but these two species are evidentiy distinct because of other differences. The genitalia of assimilis are distinct from those of caementarium, proving that assimilis is not a variety of caementarium, as it was considered by Kohl who described this form under the name nicaraguanum.

\section{CLASSIFICATION AND ANALYTICAL KEYS}

The genus Sceliphron belongs, according to Comstock ${ }^{2}$, to the Sphecinae, one of the six subfamilies into which his family Sphecidae is divided, but the subfamily Sphecinae of Comstock is equivalent to the family Sphecidae of Ashmead. For the present paper the classification of Ashmead is adopted, and the following key to the subfamilies of the family Sphecidae is that proposed by him $^{3}$ and later used by Fernald in his Digger Wasps of North America ${ }^{4}$; the groups here given subfamily rank are considered tribes by Comstock.

Following the key to the subfamilies is a key to the genera of the Sceliphroninae, also taken from Ashmead. ${ }^{5}$

$$
\text { KEY TO SUBFAMILIES OF SPECIDAE }
$$

1. Second cubital cell receiving only the first recurrent vein; the second recurrent vein received by the third cubital cell, or at least beyond the second transverse cubital. (Both recurrent veins are received by the first cubital cell in a few extra-limital forms) $-2$

Second cubital cell receiving both recurrent veins, or the second recurrent vein is interstitial with the second transverse cubitus, although sometimes the first recurrent is interstitial with the first transverse cubitus or then received by the first cubital cell

2. Antennae inserted on the middle of the face; claws with one to six teeth beneath; tibiae strongly spinous, or at least never with weak or feeble spines; tarsal comb in female present (except in Isodontia)

Chlorioninae (Sphecinae Authors).

Antennae inserted far anterior to the middle of the face; claws, simple, without teeth, or at most with a single small tooth near the middle; tibiae smooth, not spinous; tarsal comb in female never present

Podiinae.

3. Claws simple, without a tooth beneath; tibiae more or less spinous, tarsal comb in female present; abdomen most frequently very elongate, the petiole composed of two segments, rarely of only one segment; cubital cell of hind wings usually originating beyond the transverse median vein.

Sphecinae (Ammophilinae Authors).

\footnotetext{
2 Comstock: An Introduction to Entomology, 1924. Classification of the family Sphecidae, pp. 962-972; account of subfamily Sphecinae on pp. 966-967.

${ }^{3}$ Ashmead : Can. Ent., vol. 31, 1899, pp. 347-352.

${ }^{4}$ Fernald: Digger Wasps of North America, Proc. U. S. Nat. Mus., vol. 31, 1906, p. 308.

5 Ashmead : Can. Ent., vol. 31, 1899, p. 352.
} 
Claws simple, with a single tooth beneath, although sometimes very minute, more rarely without a tooth; tarsal comb in female absent; abdomen always with a one-segmented petiole; cubital vein of hind wings interstitial or nearly so

\section{4}

4. Antennae inserted on the middle of the face; metathorax with a large $U$-shaped area above; mesopleura not longer than the height of the thorax,

Sceliphroninae.

Antennae inserted far anterior to the middle of the face, on or just above an imaginary line drawn from the base of the eyes; metathorax without a large $U$-shaped area above; mesopleura much longer than the height of the thorax. Podiinae.

KEY TO THE GENERA OF THE SCELIPHRONINAE

Species black and yellow, not metallic; clypeus flat, at apex usually bidentate; transverse median nervure in front wings not interstitial with the basal nervure, but uniting with the median vein a little before the origin of the basal nervure; petiole of abdomen about twice as long as the median segment Sceliphron Klug.

Species metallic blue or violaceous; clypeus anteriorly tridentate; transverse median nervure in front wings interstitial with the basal nervure; petiole of abdomen not or scarcely longer than the median segment,

\section{Genus SCELIPHRON Klug}

Sceliphron KLug, Neue Schrift. Ges. naturf. Fr. Berlin, vol. 3, 1801, p. 561. Pelopoeus Latreille, Hist. nat. Crust. Insect., vol. 3, 1802, p. 334.

Genotype.-Sceliphron spirifex (Linnaeus), designated by Bingham (1897, Fauna Brit. India, Hym., vol. 1, p. 235).

The genus Sceliphron was established by Klug in 1801, including under it the following five species: spirifex (Sphex spirifex Iinnaeus), madraspatanum (Sphex madraspatana Fabricius), lunatum (Sphex lunata Fabricius), cyanea (Sphex cyanea Linnaeus), and fuscum, a new species. The fourth species, Sphex cyanea Linnaeus, had been placed in the genus $C h r y s i s$ by Linnaeus in the twelfth edition of the Systema Naturae. The fifth species, described by Klug as fuscum, had already been described by Fabricius as Sphex hemiptera. None of these species was designated by Klug as the genotype, and for nearly 100 years the genus Sceliphron was without a designated type species.

The genus Pelopeus was established by Latreille in 1802, giving as examples Sphex spirifex Linnaeus and Sphex lunata Fabricius, neither species being designated as the genotype. In 1810 Latrielle $^{7}$

${ }^{6}$ A study of the metallic blue mud-dauber wasps of the genus Chalybion Dahlbom was published in 1919 by Hutson (Trans. Amer. Ent. Soc., vol. 45, pp. 203-228, 1919), the species being placed by him in the genus Sceliphron Klug. Rohwer has since pointed out (Ent. News, vol. 32, p. 27, 1921) that the name Sceliphron Klug must be used for the black and yellow wasps of this group, because of the designation by Bingham (Fauna of British India, Hymen, vol. 1, p. 235, 1897) of spirifex Linnaeus as the genotype of Sceliphron. For the metallic blue species of mud-daubers, therefore, the name Chatybion Dahlbom must be used.

${ }^{7}$ Cons. Gen., p. 438. 
gave spirifex as an "exemple" of the genus Pelopoeus, and by opinion 11 of the International Commission of Zoological Nomenclature these examples have been given the value of type designations.

In 1897, however, Bingham designated the same species, spirifex Linnaeus, as the type of the genus Sceliphron. These two genera, now having a common genotype, become synonymous, and Pelopoeus, described a year later than Sceliphron, must fall as synonym.

Kohl's revision placed the entire subfamily under the genus Sceliphron, Chalybion taking subgeneric rank, along with a group called Hemichalybion. To the writer the group of species ordinarily placed under Sceliphron (the black and yellow forms, with the long petiole) are sufficiently distinct from the other forms in the subfamily to merit generic rank, and they are so placed here.

KEY TO AMERICAN SPECIES OF SCELIPHRON KLUG

1. Tegulae and scape of antenna black fasciatum (Lepeletier). Tegulae and at least part of scape of antenna yellow_-_-_- 2.

2. Abdominal segments bordered with yellow_-_-_-_-_-_-_-_-_-_-_-_- 3. Abdominal segments except first and rarely the second entirely black

3. Yellow border of abdominal segments wide lucae (Saussure). Yellow border of abdominal segments narrow jamaicensis (Fabricius).

4. Propodeum definitely marked off below from metathorax by a deep groove.

fistulare (Dahlbom).

Propodeum not definitely marked off below from metathorax

5. Hind legs with the basal portion of the tibiae and the greater portion of the tarsi yellow caementarium (Drury). Hind legs almost entirely black 6.

6. Females figulum (Dahlbom) or assimile (Dahlbom). Males 7.

7. Clypeus with long, slender teeth________-_______-_figulum (Dahlbom). Clypeus with short teeth, of the usual form assimile (Dahlbom).

\section{SCELIPHRON CAEMENTARIUM (Drury)}

Sphex caementaria Drury, 1770, Illustr. Nat. Hist., vol. 1, p. 105, female, male.

Sphex fiavomaculata DeGEer, 1773, Mem. hist. Insect., vol. 3, p. 588, no. 4.

Sphex lunata Fabricius, 1775, Syst. Entom., p. 347.

Sphex flavipes Fabricius, 1781, Spec. Insect, p. 444.

Sphex flavipunctata CHrIst, 1791, Naturg. d. Insect., p. 301.

Sphex affinis FABRICIUs, 1793, Ent. Syst., vol. 2, p. 203, no. 21.

Pelopoeus caementarius Westwood, Drury, 1837. Illustr. Nat. Hist., ed. 2, vol. 1 , p. 99 .

Pelopoeus architectus (Klug) LePeletier, 1845, Hist. nat. Insect. Hymen., vol. 3 , p. 313 , female.

Pelopoeus servillei Lepeletien, 1845, Hist. nat. Insect. Hymen., vol. 3, p. 313, female.

Pelopoeus solieri Lepeletier, 1845, Hist. nat. Insect. Hymen., vol. 3, p. 518, no. 18, female.

Pelopoeus canadensis Sмгтн, 1856, Cat. Hymen. Brit. Mus., vol. 4, p. 233. male.

Pelopoeus nigriventris Costa, (1862) 1864, Ann. Mus. Zool. Napoli, vol. 2, p. 60 . 
Black and yellow, the amount of yellow being extremely variable. Legs always variegated with yellow; at least part of the scape of antennae and the tegulae invariably yellow; rest of body sometimes entirely black, and sometimes with a considerable amount of yellow.

Female.-Head: Frons slightly depressed; insertion of antennae slightly elevated; upper part of cylpeus somewhat convex; clypeus bidentate or bilobed at apex, the lobes rounded; clypeus anr frons except above antennae covered with a dense black to golden pubescence, and also numerous black to brown upright hairs; antennae slender, filiform, the segments having the following relative lengths$1 / 19,2 / 5,3 / 27,4 / 22,5 / 17,6 / 15,7 / 13,8 / 12,9 / 10,10 / 10,11 / 9,12 / 10$; scape mostly yellow, bulb often fuscous, remainder of antenna black, very minutely sericeous; mandibles very dark ferruginous to fuscous, slightly hairy toward the base, with longitudinal raised lines and furrows; frons above antennae and vertex not or only slightly pubescent, but with numerous erect black to brown hairs, sparsely punctate; gena and occiput weakly punctate, and covered with coarse, erect, black or brown hairs.

Thorax: Surface of prothorax punctate, covered with long, erect, black to golden hairs; dorsal surface sometimes with a yellow spot, which may be interrupted in the middle. Mesonotum black, hairy, diensely punctate, and sometimes striate, lateral edges slightly reflexed from tegulae back; tegulae yellow; scutellum often with a yellow spot, longitudinally striate, hairy; pleural region just below the wing insertion often yellow; rest of mesopleural region black; whole mesopleural and mesosternal region hairy, punctate, sometimes minutely striate. Metathorax black, except the metanotum, which may have a median transverse yellow spot; upper part of metapleural region striate; the part just below almost entirely smooth and without hairs; posterior portion of the metathorax somewhat punctate and striate, not very definitely marked off above from the propodeum.

Propodeum: Black with often more or less yellow; sometimes with three spots of yellow-one at end of segment and one at each side just anterior to the spiracle; sometimes with two at the end of the segment; sometimes with only one or none; hairy, punctate and finely striate, the striations running obliquely up the sides and transversely across the dorsum.

Abdomen: Petiole smooth, nonpunctate or only very faintly punctate, minutely sericeous; black, yellow, or black dorsally and yellow ventrally; main portion of abdomen ovate, pointed at apex; black, except usually the first dorsal segment, which may have an irregular spot of yellow, or a smaller spot on each side, very rarely an indistinct spot of yellow on each side of second dorsal segment; 
smooth, and no more than slightly sericeous except toward the posterior end, where it is sparsely hairy and punctate.

Legs: Anterior four; coxae black; trochanters black with a yellow apical rim on the posterior and inner side; femora black proximally, yellow distally; tibiae yellow; tarsi yellow at base, the outer segments becoming fuscous. Hind legs: Coxae black; trochanters usually black, rarely fuscous or ferruginous, with a yellow apical rim on inner side; femora black; tibiae yellow basally, black distally; tarsi yellow at base, the outer segments becoming fuscous. Coxae and trochanters of all legs sparsely hairy; entire surface of legs more or less sericeous; tarsal claws fuscous to ferruginous, with a minute tooth near the middle on the inner surface; spines on legs varying from yellow to fuscous.

Wings: Transparent with a yellowish to fuscous tinge; outer margins slightly infuscated; larger veins yellowish ferruginous to fuscous; wings often with a slight violet or purple reflection.

Male.-Differs from female as follows: Slightly smaller, abdomen shorter and less acute; teeth of clypeus more pointed. Genitalia figured in Figures 16, 17, and 18. Tips of uncus curve first downward and slightly outward, then taper abruptly and recurve nearly vertically again.

Length.-Female, $17 \mathrm{~mm}$. to $26 \mathrm{~mm}$.; male, $13 \mathrm{~mm}$. to $23 \mathrm{~mm}$.

Habitat.-North, Central, and Insular America, and also reported by Kohl from Tahiti and Honolulu, and by Cameron from Brazil. There are definite records from as far north as Quebec and Vancouver, and from as far south as the Barbadoes and Costa Rica.

Types.-The only type known to be in existence is that of Smith's canadensis, in the British Museum, where it was seen by Doctor Fernald in 1913.

This species seems to come closer to assimile and figulum than any other American species. Sceliphron caementarium always has at least the basal half of the hind tibiae and the basal two segments of the hind tarsi yellow; while assimile and figutum have the hind legs almost entirely black or fuscous, the tibiae having a slight yellow streak below basally, and the two or three basal segments of the tarsus sometimes becoming yellowish. Also, with figulum the teeth of the clypeus of the male are very elongate and narrow, which is not the case with caementarium. The male genitalia of caementarium are distinct from those of assimile and figutum.

It has already been mentioned that the amount of yellow present in this species is very variable. This has led to its description under a number of different names, some being designated as distinct species and others as varieties or subspecies. With a large series of specimens, taken from many parts of America, it has been possible 
to show that the whole group is one species, though with a great amount of variation.

The amount of yellow present on the legs seems to be very nearly constant. The greater part of the scapes of the antennae and the tegulae are always yellow. The abdomen, except part of the first and very rarely part of the second dorsal segment is always black. The variation, then, occurs chiefly on the thorax, petiole, and first abdominal segment. Beginning with the form having the greatest amount of yellow, we have servillei, described by Lepeletier in 1845 . In this form, the yellow is distributed as follows: The dorsal part of the prothorax, tegulae, a streak downward below the tegulae, scutellum, metanotum, a spot on each side of the propodeum anterior to the spiracles, a very large spot on the end of the propodeum, this sometimes very much extended forwards, the entire petiole, and almost all of the first dorsal abdominal segment; all of this in addition to the constant areas previously mentioned. In some individuals, the petiole, instead of being entirely yellow, has a fuscous streak on the dorsal side; in others the same area is black; in still others almost the dorsal half is black. Parallel with this has occurred a reduction in the size of the spots on the propodeum, those at the sides tending to disappear, and that on the end being much smaller. Such specimens were described as caementarium by Drury in 1770 and as flavipunctata by Christ in 1791. Next, the amount of yellow on the ventral side of the petiole gradually lessens, until this area becomes entirely black. Such individuals were described in 1773 by De Geer as Sphex favomaculata and by Fabricius in 1775 as Sphex lunata.

From this point on, the reduction in the amount of yellow seems to take place in two principal regions-at the end of the propodeum and on the first dorsal abdominal segment. The spot at the end of the propodeum is very much reduced in size in some specimens; in some it is narrowed in the middle; and in still others it is divided, forming two small spots instead of one larger one. This form was described by Smith in 1856 as canadensis. In other cases the spot or spots at the end of the propodeum have disappeared entirely, giving a form which has not been described.

Other individuals which retain the spot at the end of the propodeum lose to a greater or less extent the yellow on the first dorsal segment of the abdomen. The lunate mark becomes divided in the middle, and the two spots thus formed may become reduced to mere dots, or disappear entirely. This variation was described in 1864 by $\mathrm{A}$. Costa as nigriventris, and in 1845 by Lepeletier as architectus.

Parallel with the reduction in the amount of yellow on the propodeum and abdomen has occurred a similar reduction in the amount of yellow on the dorsal surface of the thorax and on the 
mesopleura below the bases of the wings. When the yellow has all disappeared except that on the tegulae, we have the form described by Fabricius as Sphex flavipes. Saussure speaks of variations of favipes in which there is present a yellow subalar mark and others in which the scutellum and metanotum may have yellow fasciae.

From a study of this series, it is evident that there is a gradual variation from the servillei form, with a large amount of yellow, down to the flavipes variation, with no yellow except on the legs, tegulae, and scapes of the antennae. While in a general way the forms with the greatest proportion of yellow are more common in the more southern localities, none of the different forms are restricted to any distinct region. No essential structural differences are found through the series. A detailed study of the male genitalia have shown them to be identical throughout the group. It is thus evident that the entire group consists of but one species, which was first described by Drury as caementarium.

\section{SCELIPHRON ASSTMILE (Dahlbom)}

Pelopoeus assimilis DАнцвом, 1843, Hymen. Europ., vol. 1, p. 23, no. 7 , female, male.

Sceliphron caementarium DruRy, var. nicaraguanum KoHL, 1918, Annalen des Naturhistorischen Hofmuseums Wien, vol. 32, p. 118.

Black and yellow, the yellow distributed as follows: Scapes of antennae, rorsal region of prothorax, scutellum, metanotum, tegulae, a streak below the tegulae, usually a spot on each side of the propodeum anteriorly and one at end, sometimes the ventral side of the petiole, an irregular spot or spots on first dorsal abdominal segment, and parts of legs.

Female.-Head: Frons slightly concave, insertion of antennae slightly elevated; anterior margin of clypeus bilobed or bidentate, the lobes rounded; clypeus and frons covered with a dense golden pubescence which is thinner or absent above antennae, and also with numerous black to golden upright hairs; antennae slender, filiform, the segments having the following relative lengths: $1 / 19,2 / 4,3 / 31$, $4 / 23,5 / 19,6 / 15,7 / 13,8 / 12,9 / 11,10 / 10,11 / 9,12 / 10$; scape yellow, bulb fuscous, remainder of antenna black, very minutely sericeous; mandibles very dark ferruginous to fuscous, slightly hairy towards base, with longitudinal lines and furrows; vertex, genae, and occiput not pubescent or only slightly so, but with numerous erect black to golden hairs, and weakly punctate.

Thorax: Dorsal region of prothorax with a large yellow spot; surface weakly punctate, covered with long erect, black to golden hairs. Mesonotum black, hairy, densely punctate, and somewhat striate, scutellum transverse, longitudinally striate, with a large yellow spot, hairy; tegulae yellow; area just below tegulae yellow, rest of $3017-26-2$ 
mesopleural region black; whole pleural and sternal region hairy, punctate, sometimes minutely striate. Metathorax black except metanotum, which has a linear transverse yellow spot; upper and anterior part of metapleural region striate, the part just below almost entirely smooth and without hairs; posterior part of metathorax somewhat punctate and slightly striate, not very definitely marked off above from the propodeum.

Propodeum: Hairy, punctate and striate; black, usually with three yellow spots, one on each side anterior to the spiracle, and one at the end above the petiole, this spot varying somewhat in size, but usually covering the entire end of the propodeum and extending forward a short distance along each side.

Abdomen: Petiole smooth, nonpunctate or only faintly punctate, minutely sericeous, black, sometimes with ventral part yellow to brown; main portion of abdomen ovate, pointed at apex, black except first dorsal segment, which usually has an irregular yellow area; smooth, and no more than slightly sericeous except the last dorsal and ventral segments, which are sparsely hairy and punctate.

Legs: Anterior four: coxae black, trochanters black with a yellow to brownish apical rim behind; femora black proximally, yellow distally; tibiae yellow; tarsi yellow at base, the outer segments becoming fuscous. Hind legs: almost entirely black; trochanters with yellow to brown apical rim on lower side; tibiae with yellow streak on lower surface basally; tarsi usually black, but sometimes fuscous, with first segment or two ferruginous below. Coxae and trochanters of all legs sparsely hairy; entire surface of legs more or less sericeous; tarsal claws fuscous, with a very minute tooth near the middle on the inner surface; spines on legs varying in color from yellow to fuscous.

Wings: Transparent with a yellowish or brownish tinge, often with a violet or purple reflection; outer margins slightly infuscated; larger veins ferruginous to fuscous.

Male.-Differs from female as follows: slightly smaller; abdomen shorter and less acute; teeth of clypeus a little longer and less broadly rounded than those of the female; sometimes a spot of yellow on the outside of the posterior trochanter.

Genitalia: Somewhat similar to those of caementarium, but the tips of the uncus taper and curve more gradually, the extreme tips pointing horizontally outward at about right angles to the main axis of the genital structures.

Length.-Female, $20 \mathrm{~mm}$. to $25 \mathrm{~mm}$; male $17 \mathrm{~mm}$. to $22 \mathrm{~mm}$.

Habitat.-The extreme southern part of Texas, Mexico, Central America, the West Indies, and the northern part of South America. It is impossible to determine the exact southern limits of this species, since the females are indistinguishable from those of figulum, the 
range of which probably extends farther south than that of assimile. The two species have been confused in the literature, which adds to the difficulty in determining the exact range of each.

Types.-The type of assimile was studied by Dr. H. T. Fernald at the University of Lund in 1913. Kohl makes no mention of the type of nicaraguanum, but his locality record reads "Nicaragua, Mus. Berol."

Notes made by Doctor Fernald on the type of assimile have greatly supplemented the original meager description, and have convinced the writer that the form under present consideration is the same as that described by Dahlbom under this name. S. figulum and assimile were both described by Dahlbom on the same page. The only difference noted was in the shade of the color of the wings and of the wing venation, which is wholly inadequate as a distinguishing character. While the original description of figutum gives the locality as "Gallia meridionalis," this was presumably an error, since in the key to the species on page 434 of the same volume the locality is given as America, and figulum has been very generally accepted as an American species. Assimile was first recorded as a Cuban species. While the two names, figulum and assimile, may have been originally used for the same form, it seems more likely that the specimens from which the description of figulum was prepared were the form next discussed in the present paper. In the uncertainty, it seems best to keep the name assimile for the only West Indian form to which these two descriptions could apply, since the type locality for assimile is Cuba, while that of figulum is unknown.

A study of the male genitalia of assimile show it to be undoubtedly distinct from caementarium, which is further evident from the constantly darker color of the posterior legs of both sexes of assimile. The form nicaraguanum, described by Kohl as a variety of caementarium, is evidently identical with assimile.

This species is undoubtedly distinct from figulum; sufficient evidence of this is offered by the unusual shape of the teeth of the clypeus of the male of the latter, which are long and slender, quite different from those of any other species of Sceliphron. I share Kohl's difficulty in distinguishing between the females of the two forms, and have been unable to find any constant difference.

\section{SCELIPHRON FIGULUM (Dahlbom)}

Pelopoeus figulus DАнцвом, 1843, Hymen. Europ., vol. 1, p. 23, no. 6, female. Pelopoeus vindex LePeletier, 1845, Hist. Nat. Insect., Hym., vol. 3, p. 317, no. 17, male.

Pelopoeus bimaculatus LePeletier, 1845, Hist. Nat. Insect., Hym., vol. 3, p. 319 , no. 19 , female.

Pelopoeus chilensis SPInola, 1851, Hist. fis. Chile Zool., vol. 6, p. 395, no. 1, female, male. 
Black and yellow, the yellow distributed as follows: Scapes of antennae, dorsal region of the prothorax, scutellum, metanotum, tegulae, a streak below the tegulae, usually a spot on each side of the propodeum and one at the end, sometimes the ventral half of the petiole, an irregular spot or spots on the first dorsal abdominal segment, and parts of the legs.

Female.-Head: Frons slightly concave, insertion of the antennae slightly elevated; anterior margin of clypeus bilobed or bidentate, the lobes rounded; clypeus and frons except above the antennae covered with a dense golden pubescence, and also numerous upright black to golden hairs; antennae slender, filiform, the segments having the following relative lengths: $1 / 19,2 / 4,3 / 26,4 / 22,5 / 17,6 / 14$, $7 / 12,8 / 11,9 / 10,10 / 10,11 / 9,12 / 10$; scape yellow, bulb fuscous, the remainder of antenna black, very minutely sericeous; mandibles very dark ferruginous to fuscous, slightly hairy toward the base, with longitudinal lines and furrows; frons above antennae, vertex, genae and occiput not or only slightly pubescent, but with numerous erect black to golden hairs, and weakly punctate.

Thorax: Dorsal region of prothorax with a large yellow spot; surface weakly punctate, covered with long, erect, black to golden hairs. Mesonotum black, hairy, densely punctate, and sometimes striate; scutellum transverse, with a large yellow spot, longitudinally striate, hairy; tegulae yellow ; area just below tegulae yellow; rest of mesopleural region black; whole pleural and sternal region hairy, punctate, sometimes minutely striate. Metathorax black except the metanotum, which has a linear transverse yellow spot; upper and anterior part of metapleural region striate; the part just below almost entirely smooth and without hairs; posterior part of metathorax somewhat punctate and striate, not very definitely marked off above from the propodeum.

Propodeum: Hairy, punctate, and striate; black, usually with three yellow spots - one on each side anterior to the spiracle, and one at the end above the petiole, this spot varying greatly in size, but usually covering the whole end of the segment and extending forward on the dorsum, leaving a central black band which in front widens to the full width of the dorsum. I have one specimen from Chile in which the propodeum is almost entirely black, suggesting the possibility of a variation similar to that occuring in caementarium.

Abdomen: Petiole smooth, nonpunctate, or only faintly punctate; minutely sericeous; black, sometimes with the ventral portion yellow; main portion of abdomen ovate, pointed at apex, black except the first dorsal segment, which has an irregular mark of yellow, sometimes interrupted in the middle; smooth, and no more 
than slightly sericeous except the last dorsal and ventral segments, which are sparsely hairy and punctate.

Legs: Anterior four: Coxae black; trochanters black with a yellow apical rim behind; femora black proximally, yellow distally; tibiae yellow; tarsi yellow at base, the outer segments becoming fuscous. Hind legs: Almost entirely black; trochanters with a yellow apical rim on inner side, and sometimes with a small yellow spot on outside; tibiae with an inconspicuous yellow streak on lower surface basally; tarsi usually black, but sometimes fuscous with the first segment or two ferruginous below. Coxae and trochanters of all legs sparsely hairy; entire surface of legs more or less sericeous; tarsal claws fuscous, with a very minute tooth near the middle on the inner surface; spines on legs varying from yellow to fuscous.

Wings: Transparent with a yellowish tinge, often with a slight violet or purple reflection; outer margins slightly infuscated; larger veins ferruginous to fuscous.

Male.-Differs from female as follows: Slightly smaller; abdomen shorter and less acute; teeth of clypeus much more pointed and elongate than those of the female, and farther apart; these teeth are distinct in form from those of any other American species of this genus; pubescence on face silvery to golden; sometimes a yellow to brown spot is present on the outside of the posterior trochanters. One male from Chile lacks the anterior yellow spots on the propodeum, and the usually large area of yellow at the posterior end of the propodeum is reduced to three small spots, which suggests the possibility of a variation in this species similar to that occuring with caementarium; in other males the yellow area at the end of the propodeum extends over into the dorsal area.

Genitalia: Similar to those of assimile.

Length.-Female, $22 \mathrm{~mm}$. to $28 \mathrm{~mm}$; male, $18 \mathrm{~mm}$. to $23 \mathrm{~mm}$.

Habitat.-Kohl records this species from numerous localities from Tampico, Mexico, southward through Central and South America, and makes one doubtful reference to a record from it from Cuba by De Saussure, which is the only record which he has from the West Indies. The writer has seen specimens from Para, Brazil, Sapucay, Paraguay, Bahia Blanca, Argentina, and from "Chile."

The probable proper applications of the names figulum and assimile and the difficulty in separating the two species have already been touched upon. If the type of figulum were available, it is possible that it might be found to be the same form as that here called assimile, in which case the latter name would have to be dropped in favor of figulum, and the form here called figulum would then be called vindex. It is, however, equally possible that Dahlbom used these names as they are used in this paper, and in the absence 
of the information which a study of the type of figulum would give, the present disposition of the respective names seems the best possible, and is the same as used by Kohl in his revision.

The descriptions of bimaculatus and vindex by Lepeletier are identical in almost every respect, and there is little doubt that these names are synonyms of figulum. As described by Spinola, chilensis differs from figulum only in having the propodeum entirely black instead of with three spots of yellow. In two specimens from Chile which the writer has studied, both male and female had a very small amount of yellow on the propodeum, represented by several faint spots at the posterior end, and none at the sides. A series would probably show a variation similar to that occurring with caementarium.

The differences between figulum and caementarium have already been noted. Superficially, figulum has also some resemblance to fistulare, but with the latter, the propodeum is marked off below by a deep, definite groove, and has six spots of yellow, neither of which features occur with figulum.

SCELIPHRON FISTULARE (Dahlbom)

Pelopoeus fistulairis Dيнивом, 1843, Hymen. Europe, vol. 1, p. 22, no. 8, 1845 ; Hymen. Europe, vol. 1, p. 434, no. 17, female, male.

Pelopoeus histrio Lepeletier, 1845, Hist. nat. Insect. Hymen., vol. 3, p. 316, no. 16, female, male.

Black and yellow; propodeum shining, strongly striate, and with six spots of yellow; pubescence golden; tarsal claws without a tooth; propodeum definitely marked off below from the metathorax by a deep groove.

Female--Head: Frons depressed, insertion of antennae slightly elevated; upper part of clypeus slightly convex; clypeus bidentate or bilobed at apex, the lobes rounded; frons except above antennae and clypeus covered with a dense golden pubescence, and also numerous erect golden hairs; antennae slender, filiform, the segments having the following relative lengths: $1 / 21,2 / 4,3 / 25,4 / 21,5 / 17,6 / 14$, $7 / 11,8 / 10,9 / 9,10 / 9,11 / 8,12 / 10$; scape yellow, bulb fuscous, remainder of antenna black, very minutely sericeous; mandibles very dark ferruginous to fuscous, without a tooth on the inner surface, slightly hairy toward the base; frons above antennae, vertex, genae, and occiput not or only slightly pubescent, but with numerous erect golden hairs, weakly punctate.

Thorax: Surface of prothorax weakly punctate, covered with long, erect, golden hairs; dorsal surface with a yellow spot; sometimes a spot at each side. Mesonotum black, hairy, densely punctate, minutely striate; scutellum with a large yellow spot, longitudinally striate, hairy; tegulae yellow; a streak below tegulae yellow; 
rest of mesopleural region shining, black; whole mesopleural and mesosternal region hairy, punctate, but not striate. Metathorax smooth, or at most only very weakly and sparsely punctate; shining black, except the metanotum, which has a linear transverse spot of yellow; metathorax very definitely marked off above from the propodeum.

Propodeum: Shining black, hairy, not noticeably punctate, but quite strongly striate; with six spots of yellow-one on each side anterior to and extending backward below the spiracles, one on each side of the dorsum, and two at the end above the base of the petiole.

Abdomen: Petiole black, with a narrow yellow line on ventral surface; almost entirely smooth; first dorsal segment with a yellow area, which is larger at the sides, sometimes almost entirely yellow; rest of abdomen black, smooth, and no more than slightly sericeous, except the last dorsal and ventral segments, which are sparsely hairy and punctate.

Legs: Anterior four: Coxae black; trochanters black with a yellow apical rim posteriorly and on outside, often with a yellow spot on anterior surface; femora with a small area of black basally, remainder yellow; tibiae yellow; tarsi yellow, the outer segments becoming fuscous. Hind legs: Coxae black with a subquadrate spot of yellow behind and often another spot on opposite side, the two often meeting; trochanters black to fuscous, with sometimes an indefinite yellowish area; femora black to fuscous with a narrow line of yellow outside; tibiae fuscous, yellow below distally; tarsi fuscous. Coxae and trochanters very sparsely hairy; surface of legs more or less sericeous, that of tibiae and tarsi especially so; spines fuscous to ferruginous; tarsal claws fuscous, without a tooth.

Wings: Transparent with a yellowish to fuscous tinge; veins fusco-ferreginous; wings often with a slight violet reflection.

Male.-Differs from female as follows: Slightly smaller; abdomen shorter and less acute; teeth of clypeus pointed, not broadly rounded. One otherwise typical male with the middle pair of spots on the propodeum missing was noted.

Genitalia: Tips of uncus not much curved; blunt, not pointed. Sagittae, volsellae, and claspers somewhat similar to those of caementarium (pl. 4, figs. 19 and 20 ).

Length.-Female, $20 \mathrm{~mm}$. to $24 \mathrm{~mm}$; male, $17 \mathrm{~mm}$. to $21 \mathrm{~mm}$.

Habitat.-Mexico, Central Insular, and South America. Cameron reports it as far north as Atoyac, Vera Cruz. The only records from Insular America are from Montserrat and St. Vincent. I have specimens from Para and Obidos, Brazil, and from Peru. How much farther south the range of this species extends I can not say.

Types.-The location of the types of this species is unknown. 


\section{SCELIPHRON FASCIATUM (Lepeletier)}

Pelopoeus fasciatus Lepelerier, 1845, Hist. Nat. Insect. Hymen., vol. 3, p. 315, no. 15 , female.

Pelopoeus argentifrons Cresson, 1865, Proc. Entom. Soc. Philadelphia, vol. 4, p. 136, female.

Shining black, with pale yellow markings on thorax and first dorsal abdominal segment; pubescence and hairs silvery; legs black.

Female.-Head: Black; frons slightly depressed, insertion of antennae slightly elevated; upper part of clypeus somewhat convex, anterior edge reflexed, bidentate or bilobed, the lobes rounded; frons except above antennae and clypeus with a dense silvery pubescence and also with numerous erect silvery hairs; antennae black, faintly sericeous, the segments having the following relative lengths: $1 / 19,2 / 4,3 / 24,4 / 18,5 / 15,6 / 13,7 / 11,8 / 9,9 / 8,10 / 7,11 / 6$, $12 / 7$; mandibles fuscous, tips ferruginous, sparsely hairy towards the base; frons above antennae, vertex, genae, and occiput not or only slightly pubescent, but with numerous erect, silvery hairs, slightly punctate.

Thorax: Prothorax shining black, with two linear spots of yellow on the dorsal surface, one on each side of the median depression, weakly punctate, covered with white hairs. Mesonotum black, densely and finely punctate and striate, hairy; scutellum with a transverse yellow spot, longitudinally striate; an area just below tegulae yellow, rest of pleural region shining black; whole mesopleural and mesosternal region hairy, punctate, and striate. Metathorax black except a narrow transverse band of yellow on the metanotum; upper and anterior part of metapleural region almost smooth and with only a few minute white hairs; posterior part slightly punctate.

Propodeum: Shining black with a spot of yellow on each side anterior to the spiracles, and two sub-circular spots of yellow at apex, above the base of the petiole; minutely punctate and striate; covered with silvery hairs.

Abdomen: Petiole shining black, slightly hairy and sericeous; main portion of abdomen ovate, pointed at apex, black except the first dorsal segment, which has a yellow band on its posterior margin, broadening out at the sides; nonpunctate and not more than very slightly sericeous except the last dorsal and ventral segments, which are hairy and punctate.

Legs: Black; more or less silvery sericeous, the tarsi being especially so; coxae and trochanters, and sometimes the femora, sparsely hairy; tarsal claws dark ferruginous, with a minute tooth near the middle on the inner surface; spines on legs fuscous. 
Wings: Transparent with a fuscous tinge; outer margins infuscated; veins fuscous; wings often with a slight violet or purple refiection.

Male-Differs from female as follows: Anterior margin of clypeus nearly straight; anterior tibiae usually with an elongate yellow spot; middle tibiae often with a very small yellow spot; tarsal claws without a tooth.

Genitalia: Uncus slender, tips bent at right angles to main axis; volsellae broad (pl. 4, figs. 21 and 22 ).

Length.-Female, $19 \mathrm{~mm}$. to $22 \mathrm{~mm}$.; male, $17 \mathrm{~mm}$. to $19 \mathrm{~mm}$.

Habitat.-Isle of Pines, Haiti, and Cuba.

Types.-The location of Lepeletier's type is unknown. The type of Cresson's argentifrons is in the collection of the Entomological Society of Philadelphia.

Kohl appeared to be in doubt whether fasciatum and argentifrons were the same and chose to use the latter name. In both original descriptions the tegulae and all legs were noted as being entirely black. These characters constitute a departure from the usual condition among American species of Sceliphron. The writer has seen only one form in which these characters occur, and it seems evident that there is only one species involved.

\section{SCELIPHRON JAMICENSIS (Fabricius)}

Sphex jamaicensis Fabricius, 1775, Syst. Entom., p. 347, no. 10.

Pelopoeus jamaicensis Fabricius, 1804, Syst. Piez., p. 204, no. 6.

Pelopoeus annulatus Cresson, 1865, Proc. Ent., Soc. Philadelphia, vol. 4, p. 135, female, male.

Pelopoeus vindex, var. annulatus Cresson, Saussure, 1867, Reise d. Novara Zool., vol. 2, pt. 1, Hymen., p. 32, female.

Black or fuscous and yellow, posterior margins of all segments yellow, pubescence and hairs yellow.

Female.-Head: Frons slightly depressed; insertion of antennae slightly elevated; upper part of clypeus somewhat convex; clypeus bilobed or bidentate at apex, the lobes rounded, frons except above antennae and clypeus covered with a dense golden pubescence and numerous erect golden hairs; antennae slender, filiform, the segments having the following relative lengths: $1 / 20,2 / 5,3 / 25,4 / 20$, $5 / 17,6 / 14,7 / 11,8 / 10,9 / 10,10 / 9,11 / 8,12 / 9$; scape yellow, bulb fuscous; second segment fuscous above, yellow below; third segment yellow basally below and at tip, rest fuscous; fourth and fifth segments sometimes with a little yellow at tip; rest of antenna black, very minutely sericeous; mandibles very dark ferruginous to fucous, slightly hairy toward the base; frons above antennae, vertex, 
genae, and occiput not or only slightly pubescent, but with numerous erect golden hairs, somewhat punctate.

Thorax: Surface of prothorax punctate, covered with long, erect, golden hairs; dorsal surface almost completely covered with a yellow spot, which usually extends downward on each side nearly to the coxa. Mesonotum black, hairy, densely punctate, minutely striate; scutellum with a large transverse yellow spot, longitudinally striate; tegulae yellow; an area just below the tegulae yellow; rest of mesopleural region black; whole mesopleural and mesosternal region hairy, punctate, sometimes minutely striate. Metathorax black except the metanotum, which has a transverse yellow spot; upper and anterior portion of metapleural region almost entirely smooth and without hairs; posterior portion of metathorax not very definitely marked off above from the propodeum.

Propodeum: Black, with three yellow spots-one on each side at the anterior end, each of these extending posteriorly and downwards to a point; and one at the end of the propodeum extending forwards on the dorsum, leaving a central black band, which in front widens to the full width of the dorsum; surface of propodeum punctate and finely striate.

Abdomen: Petiole smooth, nonpunctate or nearly so; minutely sericeous; black dorsally and yellow ventrally, the limits of the two colors varying greatly; main portion of abdomen ovate, pointed at end; first segment yellow, with a fuscous stain above petiole; rest of segments fuscous to black, posterior margins yellow; surface smooth, no more than slightly sericeous except the last dorsal and ventral segments, which are sparsely hairy and punctate.

Legs: Anterior four: Coxae black; trochanters black with a yellow apical rim on outside; femora black basally, the remainder yellow; tibiae yellow; tarsi yellow at base, the outer segments becoming fuscous. Hind legs: Coxae black; trochanters yellow with a fuscous apical rim; femora yellow basally, the remainder black; tibiae yellow basally, black distally; tarsi yellow and fuscous, first segment usually fuscous at base and apex, the others yellow at base and fuscous at apex, outer segments becoming entirely fuscous. Coxae and trochanters of all legs very sparsely hairy; entire surface of legs more or less sericeous; tarsal claws fuscous, with a minute tooth near middle on the inner surface; spines on legs varying from yellow to fuscous.

Wings: Transparent, with a yellowish to ferruginous tinge; outer margins slightly infuscated; wings sometimes with an extremely slight violet or purple reflection.

Male.-Differs from female as follows: Slightly smaller; abdomen shorter and less acute; teeth of clypeus more pointed than in female; 
anterior portion of scape, first segment of filament, lower side and tip of second segment, yellow to ferruginous.

Length.-Female, $19 \mathrm{~mm}$. to $23 \mathrm{~mm}$.; male, $20 \mathrm{~mm}$. (one specimern). Habitat.-Haiti, the Bahamas, Cuba, Jamaica.

Types.-The location of Fabricius's types is unknown. That of Cresson's annulatus is in the collection of the Entomological Society of Philadelphia.

As this species seems to be the only one from Jamaica or the West Indies in which the segments of the abdomen are bordered with yellow, there seems to be little doubt that it was the one described by Fabricius as jamaicensis. He does not mention the presence of yellow on the petiole, but that feature may have been overlooked, or he may have described from specimens in which the petiole was entirely black, which would have been quite possible considering the variation which occurs elsewhere in this genus. This species is somewhat similar to lucae, but with the latter species the yellow borders of the abdominal segments are much wider. The two are also very widely separated geographically.

\section{SCELIPHRON LUCAE (Saussure)}

Pelopoeus lucae SAussure, 1867, Reise de Novara Zool., vol. 2, pt. 1, Hymen., p. 30 , no. 1 , female, male.

Black and yellow, posterior margins of all abdominal segments with a broad band of yellow; pubescence and hairs yellow.

Female.-Head: Frons slightly depressed, insertion of antennae slightly elevated; upper part of clypeus somewhat convex; clypeus bidentate or bilobed at apex, the lobes rounded; frons except above antennae and clypeus covered with a dense golden pubescence and numerous erect golden hairs; antennae slender, filiform, the segments having the following relative lengths: $1 / 24,2 / 5,3 / 27,4 / 24,5 / 18$, $6 / 15,7 / 12,8 / 12,9 / 11,10 / 10,11 / 9,12 / 9$; scape yellow, bulb fuscous, second segment yellow, third segment fuscous above, yellow below; rest of antennae black, minutely sericeous; mandibles ferruginous to fuscous, sparsely hairy near base; frons above antennae, vertex, genae, and occiput not or only slightly pubescent, but with numerous erect golden hairs, weakly punctate.

Thorax: Surface of prothorax weakly punctate, covered with long, erect, golden hairs; dorsal surface almost completely occupied by a yellow area; sides of prothorax with another yellow spot. Mesonotum black, hairy, densely punctate, minutely striate; scutellum with a large transverse yellow spot, longitudinally striate; tegulae yellow; an area just below the tegulae yellow; rest of mesopleural region black, except rarely a few small spots of brown; whole mesopleural and mesosternal region hairy, punctate. Metathorax black except the metanotum, which has a transverse yellow spot; upper and 
anterior portion of metapleural region nearly smooth and without hairs; posterior portion not very definitely marked off above from the propodeum.

Propodeum: Black with three yellow spots-one on each side at anterior end, each of these extending downward and posteriorly to a point, and one at the end of the propodeum extending forwards on both sides of and extending over on the dorsum; propodeum punctate, finely striate, and hairy.

Abdomen: Petiole smooth, nonpunctate, minutely sericeous in places, yellow to ferruginous; abdomen long, ovate, pointed at apex; first segment yellow, with a fusco-ferruginous stain above petiole; rest of segments black anteriorly, yellow posteriorly, smooth, and no more than slightly sericeous except the last dorsal and ventral segments, which are sparsely hairy and punctate.

Legs: Anterior four: Coxae black, often ferruginous at tip; trochanters ferruginous; femora ferruginous at base to yellow at tip; tibiae yellow; tarsi yellow, the outer segments becoming ferruginous. Hind legs: Coxae black, ferruginous at tip; trochanters ferruginous; femora ferruginous at base, the rest fuscous to black; tibiae yellow, black distally; tarsi yellow, the outer segments probably becoming ferruginous or fuscous (only two specimens were available, and both of these lacked the last two tarsal segments). Coxae and trochanters very sparsely hairy; entire surface of legs more or less sericeous; tarsal claws ferruginous, with a minute tooth near the middle on the inner surface; spines on legs varying from yellow to fuscous.

Wings: Transparent "with a ferruginous tinge; outer margins slightly infuscated; wings sometimes with an extremely slight violet reflection.

Male.-Only one male was available for study, and that one was extremely small, and may have been abnormal in other respects. Differed from female as follows: Petiole entirely black; teeth of clypeus more pointed; abdomen shorter and less acute.

Genitalia: Practically the same as those of caementarium (figs. 16,17 , and 18).

Length, female, $20 \mathrm{~mm}$. to $24 \mathrm{~mm}$; male, $14 \mathrm{~mm}$. (As already mentioned, only one male was available for study, and this one was probably unusually small.)

Habitat.-California, Lower California.

Type.-Probably in the Saussure collection at Geneva.

UNIDENTIFIED AND OTHER SPECIES

The following species have been described as occurring within the geographical limits of this paper, but have been unrecognized or should be placed in other genera. 


\section{SCELIPHRON ARGENTIPILE (Provancher)}

Pelopoeus argentipilis Provancher, 1887, Addit. faun. Canada, Hymen., p. 256, female.

An examination of the type at Quebec by the late F. W. L. Sladen at the request of the late Dr. C. Gordon Hewitt proved it to be not a Sceliphron, but presumably a Sphex.

\section{SCELIPHRON FUSCUM (Lepeletier)}

Pelopoeus fuscus Lepeletier, 1845, Hist. Nat. Insect, Hymen., vol. 3, p. 311, no. 9, female.

The habitat of this form is unknown. I have been unable to recognize the species, and it probably does not occur in America. Whatever its identity, the name fuscum must be rejected, it having been previously used by Klug for one of the species originally included in the genus Scetiphron.

\section{SCELIPHRON PETIOLATUM (Drury)}

Sphex petiolatus Drury, 1773, Illustr. Nat. Hist., vol. 2, p. 75, pl. 39, fig. 7.

Pelopoeus petiolatus Westwood, Drury, 1837, Illustr. Nat. Hist., Ed. $2^{\text {a }}$, vol. 2, p. 85 , pl. 39 , fig. 7 .

This species was described by Drury from Jamaica, but it has been unrecognized since, and I have been unable to place it. From a study of Drury's description and plates I judge that this species is not a Sceliphron.

\section{EXPLANATION OF PLATES}

[From drawings made by the author]

\section{Plate 1}

Fig. 1. Dorsal view of thorax of female Sceliphron caementarium (Drury).

2 . Side view of thorax and abdomen of female caementarium.
$a$, prothorax.
$a_{1}$, prothoracic lobe.
$d_{2}$, side of propodeum.
ac, anterior coxa.
$d_{3}$, end of propodeum.
$b_{1}$, mesonotum.
$d_{4}$, spiracle in propodeum.
$\boldsymbol{b}_{2}$, scutellum.
$f$, funiculus.
$b_{3}$, prepectus.
$f w$, fore wing.
$c_{1}$, metanotum.
$h w$, hind wing.
$c_{2}$, anterior portion of meta-
me, middle coxa.
thorax.
$c_{3}$, posterior portion of meta- thorax.
$p$, petiole.
$p c$, posterior coxa.
$s$, spiracle in 1st dorsal ab-
$d_{1}$, dorsum of propodeum.
dominal segment.
$t$, tegula.

3. Front view of head of female caementarium.

4. Tarsal claw of caementarium.

5. Tarsal claw of fistulare. 


\section{Plate 2}

Fig. 6. Wings of caementarium with the veins named according to the usual nomenclature.

$\begin{array}{lcc}a, \text { anal. } & r e_{1}, 1 \text { st recur- } & t c_{1}, 1 \text { st trans- } \\ a x, \text { axillary. } & \text { rent. } & \text { verse cubi- } \\ b, \text { basal. } & r e_{2}, \text { 2nd recur- } & \text { tal. } \\ c, \text { costal. } & \text { rent. } & t c_{2}, 2 \text { nd trans- } \\ c u, \text { cubital. } & s, \text { stigma. } & \text { verse cubi- } \\ d, \text { discoidal. } & s c, \text { subcostal. } & \text { tal. } \\ f \text {, fold. } & s d, \text { subdiscoi- } & t c_{3}, 3 \text { rd trans- } \\ f f, \text { frenal fold. } & \text { dal. } & \text { verse cubi- } \\ f h, \quad \text { f r e n a } & s i, \text { sinus. } & \text { tal. } \\ \text { hooks. } & t c, \text { transverse } & t m, \text { transverse } \\ m \text {, median. } & \text { cubital. } & \text { median. } \\ r, \text { radial. } & & \end{array}$

7. Wings of caementarium with the cells named according to the usual nomenclature.

$\begin{array}{lll}a, \text { anal. } & c u_{1}, \text { first cubital. } & d_{2} \text {, second discoidal. } \\ a p_{1}, \text { first apical. } & c u_{2} \text {, second cubital. } & d_{3} \text {, third discoidal. } \\ a p_{2} \text {, second apical. } & c u_{3}, \text { third cubital. } & m \text {, median. } \\ c \text {, costal. } & c u_{4}, \text { fourth cubital. } & r \text {, radial. } \\ c u, \text { cubital. } & d_{1} \text { first discoidal. } & s m \text {, submedian. }\end{array}$

8. Tip of anterior tibia and base of first tarsal segment of caementarium showing cleaning apparatus.

9. Tip of posterior tibia and base of first tarsal segment of caementarium showing cleaning apparatus.

\section{Plate 3}

Fig. 10. Clypeus of male caementarium.

11. Clypeus of female caementarium.

12. Clypeus of male fasciatum.

13. Antenna of female caementarium.
b, bulb.
$p$, pedicel.
fil, filament.
$s$, scape.

14. Mandible of male caementarium.

15. Mandible of female caementarium.

16. Ventral view of genitalia of male caementarium.
cla, clasper.
$u$, uncus.
co., basal ring.
vo, volsella.

$s a$, sagitta.

\section{Plate 4}

Frg. 17. Uncus of caementarium.

18. Volsellae and sagittae of caementarium.

19. Volsellae and sagittae of fistulare.

20. Uncus of fistulare.

21. Uncus of fasciatum.

22. Volsellae and sagittae of fasciatum. 


\section{$2 \mathrm{BHL}$ Biodiversity Heritage Library}

Porter, Bennett A. 1926. "American wasps of the genus Sceliphron Klug." Proceedings of the United States National Museum 70(2650), 1-22. https://doi.org/10.5479/si.00963801.70-2650.1.

View This Item Online: https://www.biodiversitylibrary.org/item/53444

DOI: https://doi.org/10.5479/si.00963801.70-2650.1

Permalink: https://www.biodiversitylibrary.org/partpdf/52000

\section{Holding Institution}

Smithsonian Libraries

\section{Sponsored by}

Smithsonian

\section{Copyright \& Reuse}

Copyright Status: Public domain. The BHL considers that this work is no longer under copyright protection.

This document was created from content at the Biodiversity Heritage Library, the world's largest open access digital library for biodiversity literature and archives. Visit BHL at https://www.biodiversitylibrary.org. 